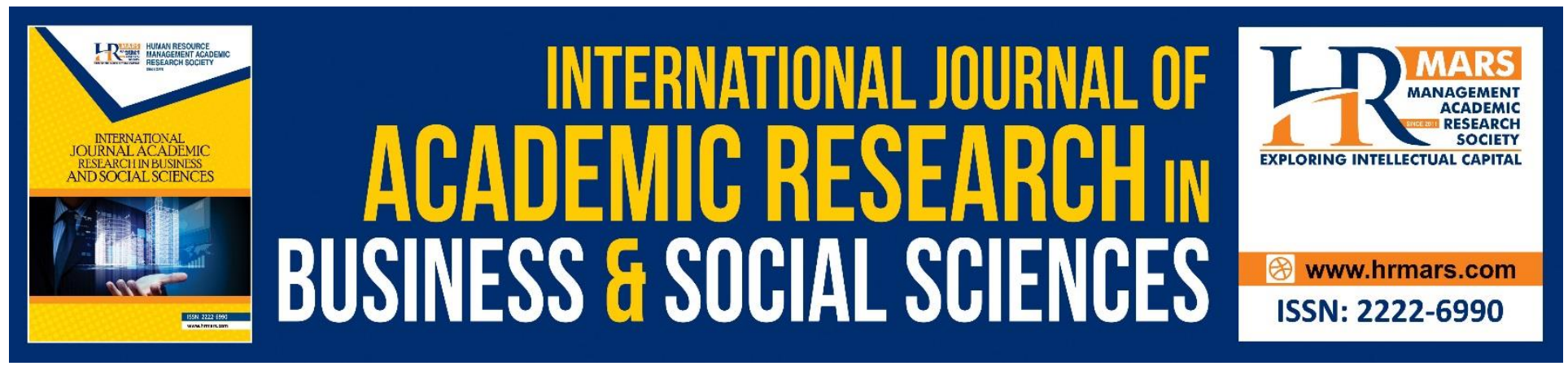

\title{
Designing a Case Study Template for Theory Building
}

\author{
M. Halizahari
}

To Link this Article: http://dx.doi.org/10.6007/IJARBSS/v8-i12/5435

DOI: $10.6007 /$ IJARBSS/v8-i12/5435

Received: 09 Nov 2018, Revised: 11 Dec 2018, Accepted: 30 Dec 2018

Published Online: 13 Jan 2019

In-Text Citation: (Halizahari, 2018)

To Cite this Article: Halizahari, M. (2018). Designing a Case Study Template for Theory Building. International Journal of Academic Research in Business and Social Sciences, 8(12), 2240-2249.

\section{Copyright: (c) 2018 The Author(s)}

Published by Human Resource Management Academic Research Society (www.hrmars.com)

This article is published under the Creative Commons Attribution (CC BY 4.0) license. Anyone may reproduce, distribute, translate and create derivative works of this article (for both commercial and non-commercial purposes), subject to full attribution to the original publication and authors. The full terms of this license may be seen at: http://creativecommons.org/licences/by/4.0/legalcode

Vol. 8, No. 12, 2018, Pg. 2240 - 2249

Full Terms \& Conditions of access and use can be found at http://hrmars.com/index.php/pages/detail/publication-ethics 


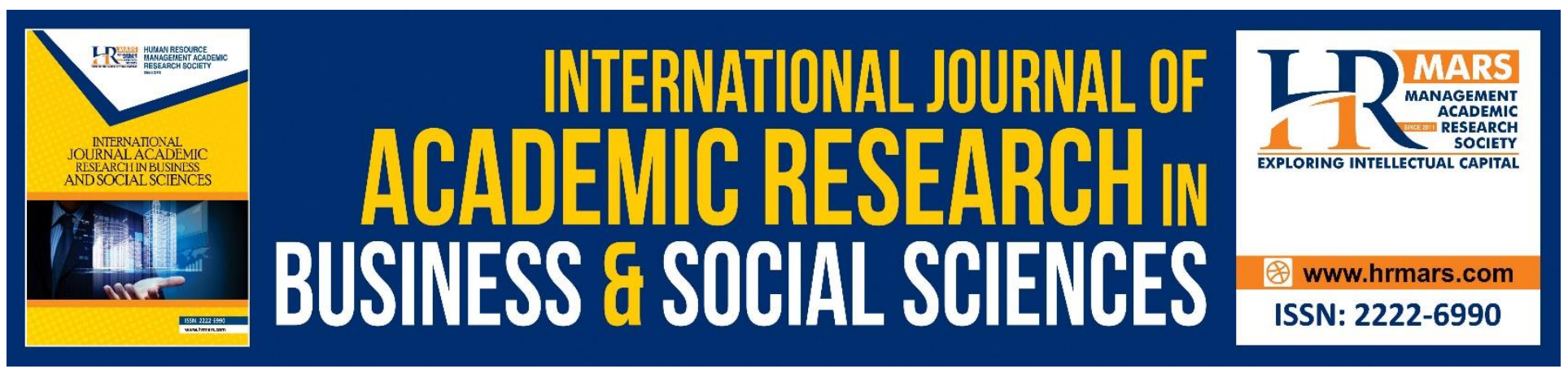

\title{
Designing a Case Study Template for Theory Building
}

\author{
M. Halizahari \\ Faculty of Defence Studies and Management, National Defence University of Malaysia. \\ Email: haliza.mz@upnm.edu.my
}

\begin{abstract}
The case study methodology is often little detail known compare to quantitative methodology. Objective of this paper is used as a guideline to the novice researcher in designing and preparing qualitative case study methodology. This guideline will be used as a structure that govern the research. It is very useful for the novice researcher in uniformity of the procedure starting from Model Development until Model Refinement phase. The content is based on the author experience from conducting case study. This Case Study Template will enable the novice researcher to execute their case study with strategies. This guideline not only practical but consistent for conducting case study for theory building.

Keywords: Case Study, Theory Building, Qualitative, Research Design
\end{abstract}

\section{Introduction}

In order to systematically conduct data collection and perform data analysis, it is vital to have a good Case Study Template (CST). It is the guideline that contains the research design, and the procedures used in conducting research as the instrument to carry out the research. By having a CST, the Researcher can use this protocol as a strategy to perform the study and act as a guide in conducting the research (Pervan \& Maimbo, 2005) in order to achieve consistency in data collection and data analysis Yin, (2003). Therefore, the purpose of this paper is to guide the novice researcher in understanding the elements of qualitative research for theory building in a case study. In this paper, the researcher will explore the case study methodology by Eisenhardt, (1989). This approach will help facilitate and aid the novice researcher in applying a suitable qualitative research methodology in building their theory by using CST.

\section{Case Study Approach}

There are varies methodologies in Qualitative Research, this paper focuses mainly on the Case Study approach by Eisenhardt, (1989). The case study is the hardest type of research in the absence of a routine formula (Yin, 2003). This type of research is used in exploring phenomenon through an in-depth study with the limited scope where the design is determined based on the data collection process, data analysis and reporting. It is best suited for applied problems. A case study aims to 
provide a description, test a theory or even generate a new theory (Ketchen, Ketchen \& Bergh, 2006). Theory building case studies are beneficial when the existing theory is limited (Ketchen, Ketchen \& Bergh, 2006). In addition, building theory from a case study can involve one or more case studies (Eisenhardt \& Graebner, 2007).

\section{A Case Study Approach by Eisenhardt}

The approach by Eisenhardt, (1989) on case studies was based on the constructivism paradigm. This is a research process were the main factors in influencing the outcomes are related to human nature, namely peoples' experience, and their individual knowledge. The Constructionist approach is a close collaboration between the researcher and participant (Baxter \& Jack, 2008). This relationship gives an advantage to the researcher in a better understanding of the issues faced by the participants' as their perspective is the most important feature in the constructivism paradigm (Baxter \& Jack, 2008). The researcher built a close rapport with the participants and is aware of the issues and problems they faced (Burnard, Gill, Stewart, Treasure, \& Chadwick, 2008). These constructionist approaches were used by Eisenhardt for theory building and is a strategy that involves one or more cases (Eisenhardt \& Garbener). Since constructionist address the world from the position of other peoples' experience, the case selection is in the very early stages of the research design phase (Steenhuis \& Bruijn, 2006). This case selection is based on earlier findings.

Eisenhardt (1989) believes that the investigation of the study is specific to different types of organisation and the decision about the data that is to be gathered is taken at an early stage; consequently, the Research Questions are identified at this point. At this initial stage, the definition of the Research Questions is in broader terms. During this preliminary process, the Researcher formulates the Research Problems by identifying important variables and the potential extent and availability of any previous literature. She has also defined the process generating the Research Questions is the same process of hypothesis-testing. Such research will allow the identification of the initial framework.

This unique way of data collection has shown that the collection and analysis can be done jointly and deliver results that are consistent and overlapping (Eisenhardt \& Graebner, 2007). Data from field notes and observation were cross-case compared.

The process of theory building from case study research by Eisenhardt, (1989) has been customised by Pervan \& Maimbo,( 2005) and illustrated in Figure 1. 
INTERNATIONAL JOURNAL OF ACADEMIC RESEARCH IN BUSINESS AND SOCIAL SCIENCES Vol. 8, No. 12, Dec, 2018, E-ISSN: 2222-6990 @ 2018 HRMARS

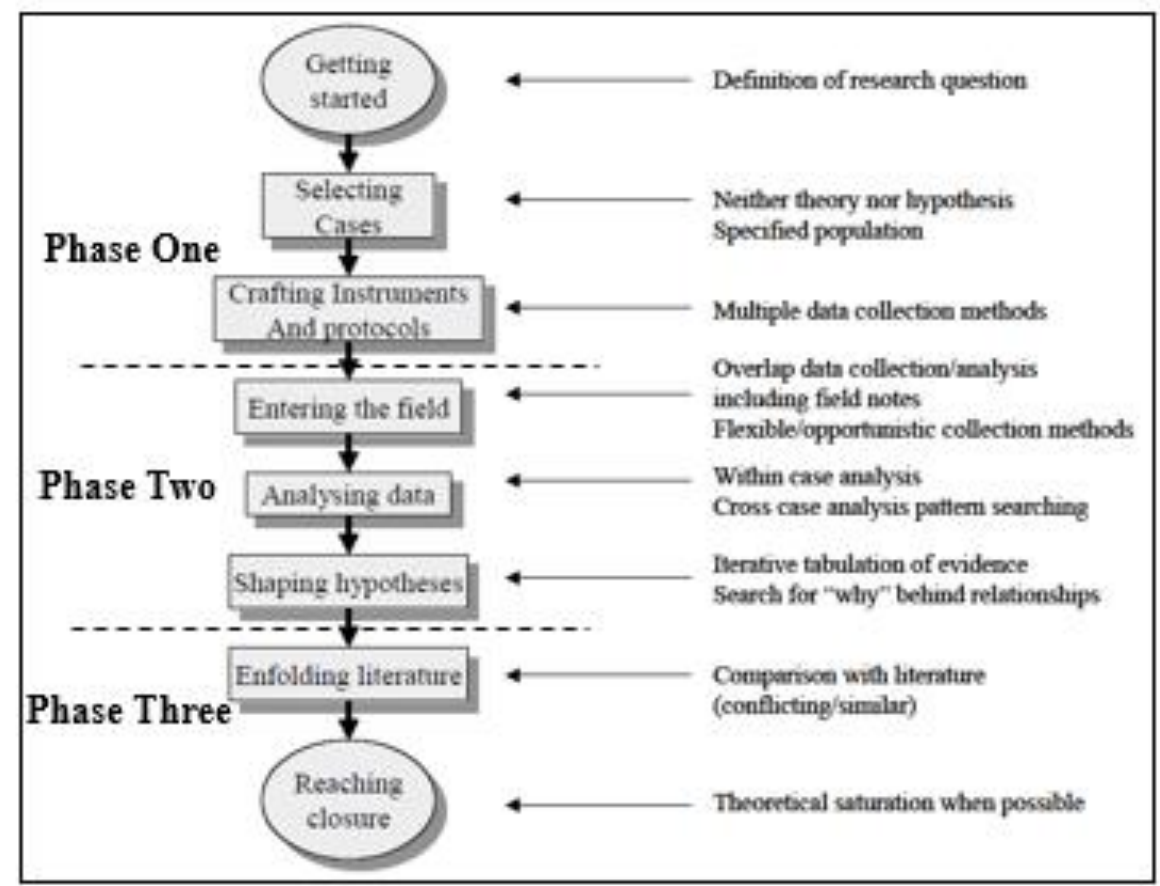

Figure 1. Process of Building Theory from Case Study Research (Eisenhardt, 1989) 
INTERNATIONAL JOURNAL OF ACADEMIC RESEARCH IN BUSINESS AND SOCIAL SCIENCES

Vol. 8, No. 12, Dec, 2018, E-ISSN: $2222-6990$ C 2018 HRMARS

Based on the framework above, the Researcher adapted key features from Eisenhardt, (1989);

Pervan \& Maimbo, (2005) and summarised in Table 1.

Table 1. Framework for Case Study Template

\begin{tabular}{|c|c|c|}
\hline Phase & Process & Activities \\
\hline \multirow[t]{3}{*}{$\begin{array}{l}\text { Model } \\
\text { Development }\end{array}$} & \multirow[t]{3}{*}{ Identify Issues and Problem } & $\begin{array}{l}\text { Getting Started } \\
\text { Identify related literature } \\
\text { Identify Research Gap } \\
\text { Propose Research Questions }\end{array}$ \\
\hline & & $\begin{array}{l}\text { Selecting Cases } \\
\text { Selecting population and using theoretical on } \\
\text { specific cases }\end{array}$ \\
\hline & & $\begin{array}{l}\text { Crafting Instruments and Protocols } \\
\text { Using multiple data collection methods. }\end{array}$ \\
\hline \multirow[t]{3}{*}{ Model Testing } & Data Collection & $\begin{array}{l}\text { Entering the Field } \\
\text { Incorporating field notes with data analysis }\end{array}$ \\
\hline & Data Analysis & $\begin{array}{l}\text { Analysing the Data } \\
\text { Within Case and Across Case }\end{array}$ \\
\hline & Data Coding & $\begin{array}{l}\text { Shaping Hypotheses } \\
\text { Iterative Tabulation of Evidence } \\
\text { The emergence of hypothesis or theoretical } \\
\text { statements } \\
\text { Replication of logic }\end{array}$ \\
\hline \multirow[t]{2}{*}{$\begin{array}{l}\text { Model } \\
\text { Refinement }\end{array}$} & \multirow[t]{2}{*}{$\begin{array}{l}\text { Finalisation of the } \\
\text { Conceptual Model }\end{array}$} & $\begin{array}{l}\text { Enfolding the Literature } \\
\text { Comparing with existing similar and conflicting } \\
\text { literature }\end{array}$ \\
\hline & & $\begin{array}{l}\text { Reaching Closure } \\
\text { Theoretical Saturation to improve existing } \\
\text { results }\end{array}$ \\
\hline
\end{tabular}


To enhance the description of Figure 1 and Table 1 the stages are presented and discussed briefly as below.

\section{Phase 1 - Model Development}

The Research Questions were generated based on the Problem Statement in order to develop a conceptual framework. The Research Questions demonstrated that the existing research did not address the problem inadequately in identifying any research gaps (Eisenhardt \& Graebner, 2007). The next, activity was theoretical sampling and was needed to select the cases that are suitable to illuminate and extend the existing theory. Theoretical sampling, regardless of a single case or multiple cases, enables the researcher to find an emergent theory.

Therefore, activities carried out in phase one can be summarised as given below:
a. Identify related literature
b. Identify Research Gap
c. Propose Research Questions

\section{Phase 2 - Model Testing}

The model testing phase consisted of two processes; data collection and data analysis. This phase began with identifying data sources. There were a variety of sources including, interviews, observations and archived data. During data collection, the instrument used to collect data was identified. Field notes and observation in the field were done to allow any adjustments of the data collection instrument (Agranoff, 2007). Upon completion, the data was analysed and validated to determine reliability and consistency.

\section{a. Data Collection}

In this phase, the conceptual model was developed based on the data collected. Instruments, such as the interview protocol, were required as a guide for the researcher to ensure that the interview sessions were controlled and the participants were comfortable answering the questions. Triangulation of data enabled a researcher to confirm and to validate the gathered data. Moreover, according to Runeson and Höst (2009), the need of triangulation is obvious when the primary data is not precise, and it also helps the researcher to look at the data from different angles.

\section{b. Data Analysis}

The data analysis method is crucial in developing and executing research (Pervan \& Maimbo, 2005). In this phase, the types of analyses were dependent on the data that had been gathered. Each case has a unique pattern that emerges which generates patterns across each case (Agranoff, 2007). According to Eisenhardt, (1989), cross case pattern can be built from:

a. Selecting categories within-group similarities coupled with inter-group differences.

b. Pair off cases by listing similarities and differences between each pair.

c. Dividing data by sources and triangulate among discussion, observation and archived documents. 
The process of data analysis was completed after the main data codes were generated. This iterative pattern analysis produced a model or framework that is supported by the coded data of evidence. Next the emergence of the hypothesis or theoretical statement fits the evidence and the replication of logic. Cases with an emergent relationship will increase validity (Agranoff, 2007).

\section{Phase Three - Model Refinement}

This phase consisted of refining and finalising the conceptual model. Refinement is a process of confirmation of relationships (Eisenhardt, 1989). Theory refinement can include the existing theory from previous studies that be extended or a new indication that can be used to develop a new theory. In many cases that are not refined, it gives an opportunity for refinement and to extend the theory before finalising.

The deliverable of this phase was a new generalised theory or conceptual model. During this phase, the final model was compared with an existing model in order to structure the research in a systematic manner.

Yin, (2003) proposed a strategy to conduct case studies by introducing Case Study Protocol. This influenced the researcher to use this strategy by developing a Case Study Template using a Process of Building Theory from Case Study Research by Eisenhardt, (1989). This CST is used as a guideline in conducting Case Studies especially for novice researchers as in Table 2.

Table 2. Case Study Template

\begin{tabular}{|c|c|c|c|c|}
\hline Phase & Stage & Activity & Sources of Data & Output \\
\hline \multirow[t]{3}{*}{ Phase One } & $\begin{array}{l}\text { Getting } \\
\text { started }\end{array}$ & $\begin{array}{l}\text { 1. Identify related } \\
\text { literature } \\
\text { 2. Identify Research Gap } \\
\text { 3. Propose Research } \\
\text { Questions }\end{array}$ & $\begin{array}{l}\text { 1. Nature or reality on } \\
\text { issues/ problems } \\
\text { 2. Comprehensive } \\
\text { literature review }\end{array}$ & $\begin{array}{l}\text { 1. Research Problem } \\
\text { 2. Research } \\
\text { Questions }\end{array}$ \\
\hline & $\begin{array}{l}\text { Selecting } \\
\text { cases }\end{array}$ & $\begin{array}{l}\text { 1. Clean theoretical slate. } \\
\text { 2. Specified population. } \\
\text { 3. Theoretical sampling }\end{array}$ & $\begin{array}{l}\text { 1. Existing theory } \\
\text { 2. Extending existing } \\
\text { theory }\end{array}$ & $\begin{array}{l}\text { 1. Single case or } \\
\text { multiple cases } \\
\text { 2. Emergent theory. }\end{array}$ \\
\hline & $\begin{array}{l}\text { Crafting } \\
\text { instrumen } \\
\text { t and } \\
\text { protocols }\end{array}$ & $\begin{array}{l}\text { 1. identifying data } \\
\text { sources } \\
\text { 2. Identified instrument }\end{array}$ & $\begin{array}{l}\text { 1. Field notes and } \\
\text { observation in the field }\end{array}$ & $\begin{array}{l}\text { 1. Multiple data } \\
\text { collection methods } \\
\text { 2. Collecting } \\
\text { qualitative evidence }\end{array}$ \\
\hline
\end{tabular}


INTERNATIONAL JOURNAL OF ACADEMIC RESEARCH IN BUSINESS AND SOCIAL SCIENCES Vol. 8, No. 12, Dec, 2018, E-ISSN: 2222-6990 @ 2018 HRMARS

\begin{tabular}{|c|c|c|c|c|}
\hline \multirow[t]{2}{*}{ Phase Two } & $\begin{array}{l}\text { Entering } \\
\text { the field }\end{array}$ & $\begin{array}{l}\text { 1. Iterative data } \\
\text { collection and analysis. } \\
\text { 2. Flexible opportunities } \\
\text { in data collection field }\end{array}$ & $\begin{array}{l}\text { 1. Field notes } \\
\text { 2. Interviews } \\
\text { 3. Archival of records } \\
\text { 3. Observation }\end{array}$ & $\begin{array}{l}\text { 1. Interview protocol } \\
\text { 2. Facilitates/identify } \\
\text { emergent themes } \\
\text { 3. Triangulation of } \\
\text { multiple data }\end{array}$ \\
\hline & $\begin{array}{l}\text { Analysing } \\
\text { data }\end{array}$ & $\begin{array}{l}\text { 1. Within case analysis } \\
\text { 2. Cross-case analysis }\end{array}$ & 1. Data codes & 1. Cross-case pattern \\
\hline \multirow[t]{2}{*}{ Phase } & Stage & Activity & Sources of Data & Output \\
\hline & $\begin{array}{l}\text { Shaping } \\
\text { hypothesis }\end{array}$ & $\begin{array}{l}\text { 1. Iterative tabulation of } \\
\text { evidence for each } \\
\text { construct } \\
\text { 2. Replication of logic } \\
\text { across cases }\end{array}$ & 1. Case evidence & $\begin{array}{l}\text { 1. Developed } \\
\text { definition and } \\
\text { measures. } \\
\text { 2. Verification of } \\
\text { evidence. } \\
\text { 3. Validation of } \\
\text { findings. } \\
\text { 4. Refinement in the } \\
\text { emergent theory }\end{array}$ \\
\hline \multirow[t]{2}{*}{$\begin{array}{l}\text { Phase } \\
\text { Three }\end{array}$} & $\begin{array}{l}\text { Unfolding } \\
\text { the } \\
\text { literature }\end{array}$ & $\begin{array}{l}\text { 1. Comparison with } \\
\text { conflicting literature } \\
\text { 2. Comparison with } \\
\text { similar literature }\end{array}$ & 1. Case evidence & $\begin{array}{l}\text { 1. Builds } \\
\text { generalisability } \\
\text { theoretical level } \\
\text { definition } \\
\text { 2. Tying the } \\
\text { emergent theory } \\
\text { with existing } \\
\text { literature }\end{array}$ \\
\hline & $\begin{array}{l}\text { Reaching } \\
\text { closure }\end{array}$ & Theoretical saturation & $\begin{array}{l}\text { 1. Case evidence } \\
\text { 2. Existing literature. }\end{array}$ & $\begin{array}{l}\text { 1. Theory } \\
\text { 2. Conceptual } \\
\text { Framework/Model }\end{array}$ \\
\hline
\end{tabular}




\section{Discussion}

This paper has discussed the Case Study approach by Eisenhardt, (1989) and the Process of Building Theory from Case Study Research. CST developed a guideline in case research. During the model development phase, the research design was discussed at the beginning stage. The researcher identified the issue/problem, related any existing literature and developed the research questions. During this phase also, research instruments were identified and any changes to instruments were allowed.

In the model testing phase, the data was collected and analysed by case or cross case to show any unique patterns which are generated across the case pattern. The hypothesis was shaped and replicated in order to refine the emergent theory.

During model refinement, the theory that is generated is compared with existing literature to find similarities and differences. The theory outcome at the end of the CST process is a complete model or framework.

\section{Conclusion}

The development of CST will successfully guide a novice researcher in conducting case research. The CST can be used to develop theory and a conceptual framework/model. By implementing a CST phase by phase consistently, it will enable novice researchers to efficiently and effectively perform their case research. These guidelines have already been successfully applied by the researcher in prior research and it is believed that the CST is practical and can be adopted in conducting other case research.

\section{Corresponding Author}

Cdr Dr Haliza binti Mohd Zahari RMN

National Defence University of Malaysia

Kem Sg Besi, 57000

Kuala Lumpur, Malaysia

Email: haliza.mz@upnm.edu.my

\section{References}

Agranoff, R. (2007). Managing within networks: Adding value to public organizations. Georgetown University Press.

Baxter, P., \& Jack, S. (2008). Qualitative Case Study Methodology: Study Design and Implementation for Novice Researchers. The Qualitative Report Volume, 13(4), 544-559. http://doi.org/10.2174/1874434600802010058

Burnard, P., Gill, P., Stewart, K., Treasure, E., \& Chadwick, B. (2008). Analysing and presenting qualitative data. British Dental Journal, 204(8), 429-432. http://doi.org/10.1038/sj.bdj.2008.292

Eisenhardt, K. M. (1989). Building Theories from Case Study Research. Academy of Management Review.

Eisenhardt, K. M., \& Graebner, M. (2007). Theory Building From Cases: Opportunities and Challenges. Academy of Management Journal, 50(1), 25-32.

Ketchen, D. J., Ketchen Jr, D. J., \& Bergh, D. D. (Eds.). (2006). Research methodology in strategy and 
management. Emerald Group Publishing.

Pervan, G., \& Maimbo, H. (2005). Designing a case study protocol for application in IS research. In The Ninth Pacific Conference on Information Systems (pp. 1281-1292).

Runeson, P., \& Höst, M. (2009). Guidelines for conducting and reporting case study research in software engineering. Empirical Software Engineering, 14(2), 131-164. http://doi.org/10.1007/s10664-008-9102-8

Steenhuis, H.-J., \& Bruijn, E. J. De. (2006). Building Theories From Case Study Research: The Progressive Case Study. In OM in the New World Uncertainties. Proceedings (CD-ROM) of the 17th Annual Conference of POMS, 28 April - 1 May 2006 (pp. 1-13). Boston, USA: Production and Operations Management Society (POMS).

Yin, R. K. (2003). Case Study Research: Design and Methods (Third). United States America: Thousand Oaks, Sage Publication.

Yin, R. K. (2011). Qualitative Research from Start to Finish. New York: Guilford Press. 